Institute of $\mathbf{F}_{\text {ood and }} \mathbf{A}_{\text {gricultural }} \mathbf{S}_{\text {ciences }}$

\title{
Management Practices to Control Tropical Soda Apple ${ }^{1}$
}

Jeff Mullahey and Pat Hogue ${ }^{2}$

Tropical soda apple (TSA) is a serious weed problem in many pastures throughout Florida. If not controlled, pasture production (yield) declines resulting in lower stocking rates, lower forage quality, and ultimately, lower ranch profitability. What is the game plan when it comes to controlling TSA?

The University of Florida, Institute of Food and Agricultural Sciences has developed Best Management Practices (BMPs) for ranchers and landowners to control TSA. These BMPs are an integrated approach involving three components: Prevention, Detection, and Control. Each rancher in Florida needs to be practicing these BMPs for three reasons: profitability, sustainability of the beef cattle industry in Florida, and to stop the spread of TSA into other states.

Remember the slogan, "An ounce of prevention is worth a pound of cure"? This is so true when it comes to TSA. Prevention means not allowing the movement of TSA onto your ranch. This plant spreads through seed that are infesting cattle, horses, hay, grass seed, sod, and contaminated mowing equipment. By not allowing these infected items onto your ranch, you are actively trying to prevent TSA from becoming a costly weed problem.
If you buy cattle and don't know where they came from, try to hold them in one pasture for six days before releasing them to other areas. Monitor this pasture for TSA plants and use control practices to remove the plants. If the cattle are infested with TSA seed and you open the gates to other pastures, then you are spreading TSA throughout your ranch. Now you have created a more difficult situation that will require more of your time and money.

Detection means knowing how to identify TSA and understanding where you are likely to find it on your ranch. If you want a positive ID of a plant you find in a pasture, take it to your local county extension livestock agent. The agent will ID the plant and then educate you on the unique characteristics of this plant such as the stickers (0.5-1 inch long), fruit color (watermelon to solid yellow at maturity), large (6-8 inches long; 3-6 inches wide) lobed-leaves, and the hairy leaf surface (sure can see the morning dew).

Control is more complicated and expensive compared to prevention and detection. If you have a sparse stand of TSA (small patches of plants scattered throughout a pasture or a low number of individual plants scattered about the pasture) then either you

1. This document is WEC 177, one of a series of the Wildlife Ecology and Conservation Department, Florida Cooperative Extension Service, Institute of Food and Agricultural Sciences, University of Florida. Original publication date: May, 2003. Visit the EDIS Web Site at http://edis.ifas.ufl.edu.

2. Jeff Mullahey, Professor and Center Director, West Florida Research and Education Center, Milton; and Patrick J. Hogue, Extension Agent III M.S. Livestock, Okeechobee County; Cooperative Extension Service, Institute of Food and Agricultural Sciences, University of Florida, Gainesville, 32611.

The use of trade names in this publication is solely for the purpose of providing specific information. UF/IFAS does not guarantee or warranty the products named, and references to them in this publication does not signify our approval to the exclusion of other products of suitable composition.

The Institute of Food and Agricultural Sciences is an equal opportunity/affirmative action employer authorized to provide research, educational information and other services only to individuals and institutions that function without regard to race, color, sex, age, handicap, or national origin. For information on obtaining other extension publications, contact your county Cooperative Extension Service office. Florida Cooperative Extension Service/Institute of Food and Agricultural Sciences/University of Florida/Christine Taylor Waddill, Dean. 
physically remove the plants (dig them with a shovel) or you spray them with a chemical. When the plants have mature fruit, try to remove them by digging and discarding them in a safe location. Herbicides that are effective for spot spraying include Remedy (DowAgriSciences) mixed at a $0.5 \%$ solution using a $0.1 \%-0.25 \%$ non-ionic surfactant or Roundup (Monsanto Corporation) mixed at a 3\% solution. You should consider adding a color marker to the herbicide solution so you know which plants have been treated. With either herbicide, spray the entire plant (all foliage) to the point of runoff on the leaves. Coverage is very important to get maximum control. Monitor the treated area for 1-2 years and re-treat when necessary (don't allow new plants to produce fruit and seed!).

Spraying dense stands (over $50 \%$ of the ground cover in a pasture is TSA) requires mowing in the spring (every 60-80 days) and then applying one quart of Remedy per acre, plus the non-ionic surfactant, in late May to early June. Monitor the treated site beginning in the fall season and spot treat all TSA plants in the pasture. Continue the monitoring and spot spraying for a period of 2-3 years. With any herbicide used, read and follow the labeled directions before using the herbicide.

Spot spraying will cost $\$ 2-\$ 5$ per acre per application compared to a cost of $\$ 25-\$ 30$ per acre for spraying dense stands. Compared to the costs associated with prevention, the costs of controlling TSA are very high. Further, with a return on investment of less than $2 \%$, cattle ranchers can not afford to spend a lot of money spraying TSA. However, Florida ranchers have to control TSA in order to stop the spread of the TSA to other states. Any restrictions on cattle movement imposed by other states will be an additional cost passed onto the producer.

No one knows better than the Florida cattlemen that TSA is a serious pasture weed problem that must be addressed. As part of your game plan to control TSA, each rancher should be practicing Prevention, Detection, and Control. Contact your local county extension agent for further information about controlling TSA. Each Florida rancher must do his/her part to help control this weed and to stop its spread to other states.
For related information on tropical soda apple, please refer to Edis documents WEC 176, Shipping Cattle, Not Tropical Soda Apple; and WEC 178, Tropical Soda Apple Making a Comeback. 